\title{
Ecology of small mammals in a Brazilian rural area
}

\author{
Paulo Sergio D'Andrea ${ }^{1}$ \\ Rosana Gentile ${ }^{2}$ \\ Rui Cerqueira ${ }^{2}$ \\ Carlos Eduardo V. Grelle ${ }^{2}$ \\ Claudia Horta ${ }^{1}$ \\ Luis Rey ${ }^{1}$
}

\begin{abstract}
A small mammal study was carried out in Pamparrão valley, Sumidouro, State of Rio de Janeiro, Brazil, from June 1991 to July 1996. The area was characterised by small rural properties with vegetable plantations, pasture lands and small forest fragments. Small mammals were captured in seven line transects along the valley. Eleven small mammal species were captured: the didelphid marsupials Didelphis aurita, Philander frenata and Monodelphis americana, and the rodents Nectomys squamipes, Akodon cursor, Oligoryzomys nigripes, Bolomys lasiurus, Oecomys concolor (Sigmodontinae), Rattus rattus (Murinae), Proechimys iheringi and Euryzygomatomys guiara (Echimyidae). The heterogeneous habitat configuration probably allowed the occurrence of marsupials and more rodent species when compared to studies in monoculture areas.

KEY WORDS, marsupials, rodents, cultivated areas, Brazil
\end{abstract}

The replacement of natural habitats by cultivated areas has been changing the structure of animal and plant communities, chiefly in relation to the composition and abundance of species. Mammals play a special role in these disturbed areas and are considered good indicators of the degree of disturbance (SOULÉ \& WILCOX 1980). Also some opportunistic species, such as herbivore and graminivorous rodents, might become agricultural plagues with extreme population peaks (MUTZE 1990; GALANTE \& CASSINI 1994). Furthermore, in rural areas, many small mammals are involved in the cycles of human parasites acting as natural reservoirs (Mello 1991; Rey 1993; Dioutaiuti et al. 1995).

The ability to understand changes in natural populations due to human disturbance is hampered by the absence of long-term studies. Small mammal populations in rural areas of Brazil are no exception. The only information available are short-term surveys carried out in monocultures (ALENCAR 1969; AMANTE 1975; CARVAlHo \& BuENo 1975; ENGEL \& MELlo 1993).

1) Departamento de Medicina Tropical, Instituto Oswaldo Cruz. Avenida Brasil 4365, 21045-900 Rio de Janeiro, Rio de Janeiro, Brasil.

2) Departamento de Ecologia, Universidade Federal do Rio de Janeiro. Caixa Postal 68020 , 21941-590, Rio de Janeiro, Rio de Janeiro, Brasil. 
While carrying out a five-year eco-epidemiological study on the role of Nectomys squamipes, the water-rat, in schistosomiasis transmission in Sumidouro, State of Rio de Janeiro, Brazil, other species of small mammals were trapped as well. This study presents general observations on the ecology of this small mammal community.

\section{MATERIAL AND METHODS}

\section{Study area}

The study was conducted in the Pamparrão valley $\left(22^{\circ} 02^{\prime} 46^{\prime \prime} \mathrm{S}\right.$, $42^{\circ} 41^{\prime} 21^{\prime \prime} \mathrm{W}$ ), an area of $1.2 \mathrm{~km}^{2}$, which is characterised by small rural properties with vegetable plantations, pasture lands and a few small Atlantic Forest fragments. The valley presents several streams and irrigation channels with some flooded areas.

The region presents humid-mesotermic climate (NIMER 1989), with a wet (November - March) and a moderately dry season (May - August). Mean monthly temperatures varied from $19.6^{\circ} \mathrm{C}$ to $27.4^{\circ} \mathrm{C}$, and monthly rainfall ranged from $0.6 \mathrm{~mm}$ to $462.9 \mathrm{~mm}$ (data obtained from Instituto Nacional de Meteorologia do Rio de Janeiro) for the five year study period.

Small mammal captures were carried out at seven line transects (A to G) along the valley. All transects were up gentle slopes, and except $\mathrm{D}$, all of them were placed along small streams. Trap spacing was $13 \mathrm{~m}$. Transects A and G were characterised by an open vegetation with sparse thickets, and no canopy in most points. Predominant plant families were Poaceae, Solanaceae, Euphorbiaceae, Fabaceae and Asteraceae. Transect B presented understory, razor grass in some points and sparse high trees. Predominant plant families were Cyperaceae, Poaceae, Verbenaceae, Asteraceae, Fabaceae, Euphorbiaceae and Solanaceae. Transect $\mathrm{C}$ had an open vegetation with razor grass, sparse shrubs and trees, with predominance of Cyperaceae, Poaceae, Onagraceae and Verbenaceae. Transect D was placed in a forest fragment in a small hill, presenting a devastated midstory and a high closed canopy. Transect $\mathrm{E}$ was placed in another forest fragment with a dense midstory and high closed canopy. Transect $\mathrm{F}$ was characterised by a continuous dense vegetation of Hedychium choronarium (Zingiberaceae).

\section{Field methods}

A preliminary species inventory was done from June 1990 until May 1991. Animals were removed for species identification based on morphology and karyotype. Voucher specimens have been deposited at Museu Nacional do Rio de Janeiro.

A capture-mark-recapture study was carried out every other month from June 1991 until July 1996. Captures were done in wire-mesh live-traps $(32 \times 18 \times 20 \mathrm{~cm})$ baited with peanut butter mixed with banana, oat and bacon on manioc slices. Each trapping session comprised five nights, except for transects E, F and G which were trapped for four nights in each session. Transects A,B,C and D had 15 trap stations, transects $\mathrm{E}$ and $\mathrm{F}$ had 10 trap stations, and transect $\mathrm{G}$ had five. Marsupials were marked by tail tattooing and rodents and pouch young by toe-clipping. During the mark-recapture study, trapped species with unknown taxonomy identification were removed to the laboratory. 


\section{Analysis methods}

Trapping rate of success (number of trapped rats/number of traps), recapture rate of individuals between sessions (number of individuals recaptured between sessions/total number of individuals) were calculated for each species and for all species together. Sex-ratio was tested by chi-square test to detect differences from 1:1 ratio in relation to the amount of individuals. The residence time was estimated as the number of days between each animal's first and last captures, except for the individuals captured in July 1996. Differences between sexes in relation to residence time were tested by Mann-Whitney test (ZAR 1996). Species diversity was estimated by Shannon index (MAGURRAM 1988) for each transect, for each month and for the entire study.

\section{RESULTS}

Eleven small mammal species were captured during the entire study: The didelphid marsupials Didelphis aurita, Philander frenata and Monodelphis americana, and the rodents Nectomys squamipes, Akodon cursor, Oligoryzomys nigripes, Bolomys lasiurus, Oecomys gr. concolor (Sigmodontinae); Rattus rattus (Muridae); Trinomys iheringi and Euryzygomatomys spinosus (Echimyidae).

Total trapping effort was of 12250 trap-nights. Figure 1 shows the number of individuals per species captured. Only individuals of the five most abundant species were mark-recaptured. The trapping success ranged from $5.8 \%$ to $23.1 \%$ with an average of $14.4 \%$, totaling 1756 captures of 540 individuals. $N$. squamipes and $D$. aurita presented not only the highest trapping rate of success but were also the most abundant species, followed by $A$. cursor, $P$. frenata, and $O$. nigripes (Tab. I). The species with the highest recapture rates of individuals were $P$. frenata, $N$. squamipes and $D$. aurita and with the total recapture rate was D. aurita (Tab. I).

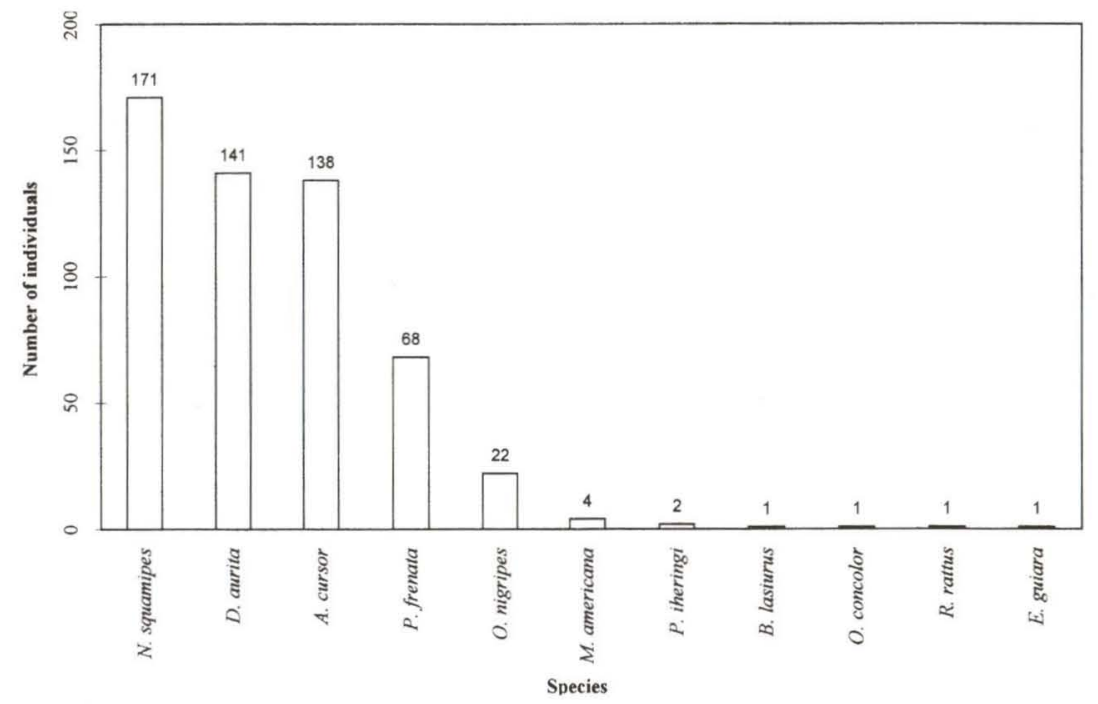

Fig. 1. Number of small mammal individuals captured per species at Pamparrão valley, Sumidouro, State of Rio de Janeiro, Brazil. 
Table I. Number of individuals captured and recaptured, recapture rates of individuals and trapping success for each species at Pamparrão valley, Sumidouro, State of Rio de Janeiro, Brazil (males/females).

\begin{tabular}{lcccccc}
\hline & D. aurita & P. frenata & N. squamipes & A.cursor & O. nigripes & Total \\
\hline Number of individuals captured & $141(71 / 70)$ & $68(44 / 24)$ & $171(104 / 67)$ & $140(81 / 59)$ & $22(18 / 4)$ & $542(318 / 224)$ \\
Number of individuals recaptured & $93(44 / 49)$ & $48(30 / 18)$ & $116(71 / 45)$ & $58(34 / 24)$ & $7(5 / 2)$ & $322(184 / 138)$ \\
Recapture rates of individuals & 65.90 & 70.60 & 67.80 & 41.4 & 31.80 & 59.40 \\
Mean trapping success & 4.71 & 2.06 & 5.14 & 2.19 & 0.26 & 14.35 \\
Minimum trapping success & 0.75 & 0.00 & 0.50 & 0.00 & 0.00 & 5.80 \\
Maximum trapping success & 9.40 & 5.30 & 12.50 & 6.80 & 1.80 & 22.80 \\
\hline
\end{tabular}

Concerning $N$. squamipes and both marsupials, an average of $60 \%$ of individuals were captured until the second day of a capture session (Tab. II). For the other two rodents, $50 \%$ of the individuals were captured only after the third day.

Table II. Mean cumulated proportion of small mammal individuals captured per day at Pamparrão valey, Sumidouro, State of Rio de Janeiro, Brazil.

\begin{tabular}{|c|c|c|c|c|c|c|}
\hline Species & Days & 1 & 2 & 3 & 4 & 5 \\
\hline D. aurita & & 42.8 & 63.4 & 75.2 & 92.0 & 100.0 \\
\hline$P$. frenata & & 31.9 & 64.0 & 76.3 & 95.4 & 100.0 \\
\hline N. squamipes & & 27.2 & 59.8 & 76.5 & 91.0 & 100.0 \\
\hline A. cursor & & 18.5 & 43.3 & 60.8 & 82.8 & 100.0 \\
\hline O. nigripes & & 9.5 & 36.5 & 66.0 & 81.7 & 100.0 \\
\hline
\end{tabular}

The small mammal diversity was $H^{\prime}=1.548$ and ranged in time from $\mathrm{H}^{\prime}=0.883$ to $\mathrm{H}^{\prime}=1.525$ (Fig. 2). Considering the whole study, transect $\mathrm{C}$ presented the highest diversity index $\left(\mathrm{H}^{\prime}=1.539\right)$, followed by transects $\mathrm{B}\left(\mathrm{H}^{\prime}=1.428\right), \mathrm{E}$ $\left(H^{\prime}=1.389\right), \mathrm{G}\left(\mathrm{H}^{\prime}=1.344\right), \mathrm{A}\left(\mathrm{H}^{\prime}=1.327\right), \mathrm{F}\left(\mathrm{H}^{\prime}=1.279\right)$, and $\mathrm{D}\left(\mathrm{H}^{\prime}=0.582\right)$.

\section{Species accounts}

\section{Didelphis aurita Wied, 1826 - common opossum}

This species occurred in all transects, mainly in areas of litter abundance, for most of its food items are found in the litter. One individual was removed and 141 were marked during the entire study. The sex ratio regarding the number of captured individuals did not differ from $1: 1\left(\mathrm{X}^{2}=0.007, \mathrm{p}>0.9\right)$. The mean residence time was 64.8 days. Females had significantly longer residence time than males $(z=3.196$, $\mathrm{p}<0.001$ ) (Tab. III), and $61.7 \%$ of the individuals were captured in only one trapping session. This species reproduced from July/August until March with two litters per breeding season and a mean litter size of seven individuals $(\mathrm{SD}=1.8$, range $=1$ to 9 , $\mathrm{N}=33$ ).

\section{Philander frenata (Olfers, 1818) - grey-four-eyed opossum}

This species was captured in all transects but predominated in forest and shrubby transects. Thirteen individuals were removed and 68 were marked. The sex-ratio regarding the number of captured individuals was $1.8: 1\left(\mathrm{X}^{2}=5.88, \mathrm{p}<0.02\right)$. $P$. frenata presented mean residence time of 50.8 days, which was not significantly 


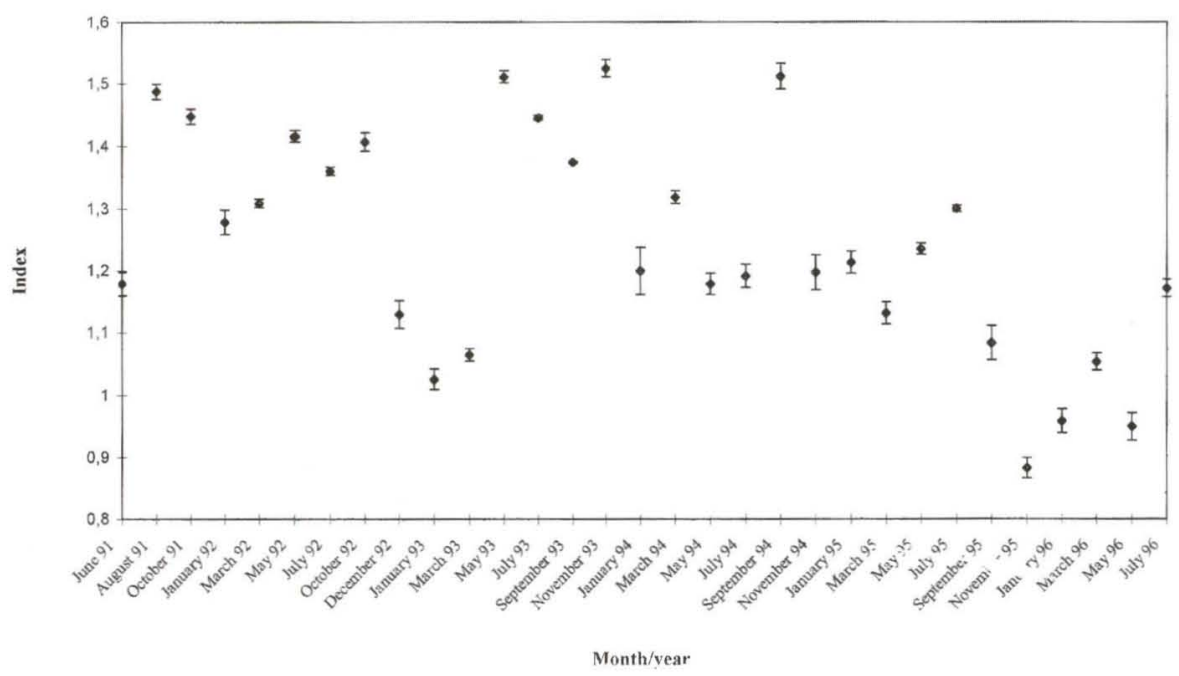

Fig. 2. Diversity of small mammals at Pamparrão valley, Sumidouro, State of Rio de Janeiro, Brazil. Circles indicate the Shannon diversity index, dashes indicate the variance of diversity.

different between males and females ( $z=0.767, \mathrm{p}>0.20)$ (Tab. III), and $64.7 \%$ of the individuals were captured in only one trapping session. They reproduced from July/August until April, with two litters per breeding season and a mean litter size of 5.4 individuals $(\mathrm{SD}=0.8, \mathrm{~N}=17)$.

Table III. Residence time (in days), standard deviations and sample size of small mammals at Pamparrão valley, Sumidouro, State of Rio de Janeiro, Brazil.

\begin{tabular}{lrrrr}
\hline & \multicolumn{1}{c}{ D. aurita } & \multicolumn{1}{c}{ P. frenata } & \multicolumn{1}{c}{ A. cursor } & \multicolumn{1}{c}{ N. squamipes } \\
\hline Total mean & $64.8 \pm 126.5(132)$ & $50.8 \pm 83.9(66)$ & $71.9 \pm 133.0(136)$ & $75.4 \pm 144.5(156)$ \\
Male mean & $21.1 \pm 41.8(68)$ & $41.8 \pm 77.7(43)$ & $67.2 \pm 151.1(79)$ & $64.4 \pm 97.7(95)$ \\
Female mean & $111.2 \pm 164.8(64)$ & $67.6 \pm 104.5(23)$ & $54.7 \pm 103.7(57)$ & $92.5 \pm 135.6(61)$ \\
Male maximum & $186(6.09$ months $)$ & $293(8.43$ months $)$ & $787(25.80$ months) & $436(14.30$ months $)$ \\
Female maximum & $629(20.60$ months) & $297(9.74$ months $)$ & $459(15.05$ months) & $490(16.07$ months $)$ \\
\hline
\end{tabular}

Monodelphis americana (Müller, 1776) - three-stripe-opossum

This species was captured only four times ( 1 male and 3 females), being all adults. No female presented pouch young. They were captured in October 1992, May 1993 and June 1993 in herbaceous vegetation under high trees (transect B and C).

\section{Nectomys squamipes (Brants, 1827) - water rat}

This species occurred in all transects, but was less abundant on the transect most distant from water (D). Eleven individuals were removed and 171 were marked. The overall sex ratio was biased to males $(1.5 \mathrm{M}: 1 \mathrm{~F} ; \mathrm{X} 2=8.006, \mathrm{p}<0.005)$. Mean residence time was 75.4 days without significant difference between sexes $(\mathrm{z}=0.588, \mathrm{p}>0.5)$ (Tab. III), and $53.8 \%$ of individuals were captured in only one 
trapping session. Reproduction was observed in all seasons with a predominance during and just after wet seasons. This species presented escape behaviour towards the water when released from the traps.

\section{Akodon cursor (Winge, 1887) - field-rat}

This species was captured in all transects, chiefly in dry areas with high herbaceous density near the ground (transects A, C, G). Twenty four individuals were removed and 140 were marked. The overall sex-ratio did not differ from 1:1 $\left(X^{2}=3.457, p>0.05\right)$. The mean residence time was 71.9 days, but $70 \%$ of the individuals were captured in only one trapping session. There was no significant difference in residence time between male and female $(\mathrm{z}=1.95, \mathrm{p}>0.50)$ (Tab. III). Reproductive activity was observed throughout the year with a slight predominance in dry seasons.

\section{Oligoryzomys nigripes (Olfers, 1818) - rice-rat}

This species was occasionally captured in the study area, in the same habitat of $A$. cursor. Ten individuals were removed and 22 were marked. The overall sex ratio was biased to males $\left(4.5 \mathrm{M}: 1 \mathrm{~F} ; \mathrm{X}^{2}=8.905, \mathrm{p}<0.005\right)$. Two individuals of $O$. nigripes were captured in more than one trapping session $(9 \%)$. One individual stayed for 75 days and the other for 175 days in the study area. Only three females were captured presenting reproductive activity in the months of July 1992, May 1993 and September 1994.

\section{Bolomys lasiurus (Lund, 1841) - field-rat}

Two adult females of this species were captured in November 1990 (pregnant) and October 1991 (non pregnant). One was captured in thypha vegetation and the other in the herbaceous vegetation of transect A.

Oecomys gr. concolor (Thomas, 1906) - rice-rat

Only two individuals were captured, one in a forest fragment (transect D) and the other on transect B. A newly-parturitioned female was trapped in November 1990 and a young male in May 1992.

\section{Rattus rattus (Linnaeu, 1758) - common-rat}

This is the only introduced species of small mammal registered in the study area. Only one pregnant female was captured on transect $G$, but they were usually found around dwellings.

\section{Trinomys iheringi Thomas, 1911 - spiny-rat}

Two females of this species were captured in August 1991 and in November 1993 on a forest fragment (transects E) and on a shrubby vegetation (transect B).

\section{Euryzygomatomys guiara Brandt, 1835 - guiara}

This species is considered rare and only one individual was captured near a bamboo vegetation of transect B in June 1991.

Two other species of mammals were found in the study area, but were not trapped: the porcupine Sphiggurus insidiosus and the armadillo Euphractus sexcinctus. 


\section{DISCUSSION}

Two other studies in cultivated areas (intensive monocultures) described communities almost restricted to rodent species [MILLS et al. (1992) six rodents representing $95 \%$ of the small mammal community; ENGEL \& MELLO (1993) seven rodents representing $100 \%$ ]. These areas presented few dominant species highly susceptible to outbreaks and crashes due to complete harvesting. Contrasting to those studies, the habitat of our study area was often modified by local harvesting, mainly grass cutting and plantation rotation activities. Featuring a heterogeneous landscape with some forest fragments, this kind of habitat configuration allowed, on the one hand, the occurrence of marsupials and more rodent species when compared to monocultures. On the other hand, the community was dominated by $D$. aurita, which is a generalist species, and by $N$. squamipes, which occurs in any kind of habitat with water courses (ERNEST \& MARES 1986), including periphery dwellings. Because the habitat of $N$. squamipes was always present along the entire study area, except for transect $\mathrm{D}$, this rodent could always be captured. In regart to $D$. aurita, our results support the hypothesis brought by FONSECA \& ROBINSON (1990), that this species predominates in disturbed areas without predators. Although ALENCAR (1969) reported damages on sugar cane fields caused by Holochilus sciureus, this has been the only registry we know of a Brazilian wild rodent behaving as an agricultural plague. Therefore, considering that there was no intensive monoculture activity in the study area, no rodent species seem likely to become an agricultural plague

Inasmuch as we observed complete landscape alteration between successive trapping sessions, the high variability in capture rate of success (from $5.8 \%$ to $23.1 \%$ ) could be partly attributed to the human disturbance at trapping transects. However, the overall mean capture rate of success was higher than studies in preserved areas of the Atlantic Forest [STALLINGS et al. (1991) 3.3\%; FONSECA \& ROBINSON (1990) 2.4\%].

Provided that in most cases, all individuals were captured until the fourth day of the trapping session, a five-day trapping session seemed to be adequate for sampling all species, especially for $D$. aurita, $P$. frenata and $N$. squamipes.

The sex ratio of captured individuals biased toward males in $P$. frenata and $N$. squamipes can also be related to differences in movement behaviour rather than unequal reproductive effort by parents or any kind of post birth selective adjustment. Data on reproductive biology in captivity of $N$. squamipes (D'ANDREA et al. 1996) and of $P$. frenata (HINGST et al. 1998) showed no significant difference neither in offspring sex ratio nor in birth and weaning body weight between sexes. We argued that because males presented more exploratory and longer movements, they were more trappable. Although there were no significant differences in residence time between sexes we observed a predominance of male movements among transects for both $N$. squamipes and $P$. frenata. GENTILE et al. (in press) also observed longer movements and larger home ranges in males of $P$. frenata.

The high variability in diversity observed along the study could be explained by temporal and spatial variation in populations as demonstrated by CERQUEIRA et 
al. (1995). The low variance in each month can be due to the large area considered in the study. The association of diversity and habitat heterogeneity can only be observed in multi-year studies such as the present one. Here, the highest diversity were observed in the three most heterogeneous transects. These results reinforce the necessity of long-term inventories in order to understand the dynamics of animal communities (CERQUEIRA et al. 1993).

The observed richness was lower than in other studies carried out in preserved areas of the Atlantic Forest, which varied from 8 to 23 species (Tab. IV). This simplifyed subset of the Atlantic Forest fauna may be explained by changes in the original vegetation resulting in the absence of arboreal mammal species due to the scarcity of trees, favouring a few generalist species considering the streamside habitat.

Table IV. A comparison of small mammal richness observed in Atlantic Forest studies.

\begin{tabular}{rll}
\hline Richness & \multicolumn{1}{c}{ Study area } & \multicolumn{1}{c}{ Reference } \\
\hline 11 & Sumidouro, Rio de Janeiro & This study \\
18 & Teresópolis, Rio de Janeiro & DAVIS 1947 \\
20 & Parque do Rio Doce, Minas Gerais & STALLINGS et. al. 1991 \\
9 & Rio Casca, Minas Gerais & FonSECA \& ROBINSON 1990 \\
11 & Caratinga, Minas Gerais & FonSECA \& ROBINSON 1990 \\
8 & Estação Ecológica da Juréia, São Paulo & BERGALLo 1994 \\
17 & Viçosa, Minas Gerais & PAGLIA et al. 1995 \\
9 & Santa Tereza, Espírito Santo & PASSAMANI 1995 \\
\hline
\end{tabular}

ACKNOWLEDGEMENTS. We thank many people who helped us during the field work: to José Wandique Fraga Costa for his assistance throughout the study, to Luana S. Maroja for helping in data analysis and for useful comments, to Lena Geise for rodent identification by karyological analysis, to the people of Pamparrão valley, Sumidouro, who allowed us to carry out the field work in their properties, and to the Sumidouro Municipal Government, in state of Rio de Janeiro, for many operational facilities. This work was supported by Instituto Oswaldo Cruz, FIOCRUZ, and grants from Conselho Nacional de Desenvolvimento Científico e Tecnológico (CNPq) and Fundação de Amparo à Pesquisa do Rio de Janeiro (FAPERJ).

\section{REFERENCES}

ALENCAR, F.O.C.C. 1969. Notas sobre o rato de cana "Holochilus sciureus" Wagner na região do Cariri, Ceará. Rev. Bras. Biol. 29 (4): 567-570.

AMANTE, E. 1975. Prejuízos causados pelo roedor Clyomys laticeps (Echimydae) em Pinnus spp., em áreas reflorestadas de Sacramento, Minas Gerais. Cienc. Cult. 27: 373-374.

Bergallo, H.G. 1994. Ecology of a small mammal community in an Atlantic Forest area of South-eastern Brazil. Studies on Neotropical Fauna and Environment. 29 (4): 197-217.

Carvalho, C.T. \& R.A. Bueno. 1975. Animais causando danos em plantios (Mammalia, Rodentia). Silvicultura, São Paulo, 9: 39-46. 
Cerqueira, R.; R. Gentile; F.A.S. Fernandez \& P.S. D’Andrea. 1993. A five-year population study of an assemblage of small mammals in Southeastern Brazil. Mammalia 57: 507-517.

Cerqueira, R; R. Gentile \& S. M.S. Guapyassú. 1995. Escalas, amostras, populações e a variação da diversidade. Oecologia Brasiliensis. 1: 131-142.

DAVIS, D.E. 1947. Notes on the life histories of some Brazilian mammals. Bol. Mus. Nac., Zool. n.s., 76: 1-8.

D'ANDREA, P.S.; C. HorTA; R. CERQUEIRA \& L. ReY. 1996. Breeding of the water rat (Nectomys squamipes) in the laboratory. Laboratory Animals 30: 369-376.

Dioutaiuti, L.; A.S. Pereire; C.F. Loiola; A.F. Fernandes; J.C. SCHOField; J.P. DUJARDIN; J.C.P. DIAS \& E. CHIARI. 1995. Inter-relation of sylvatic and domestic transmission of Trypanosoma cruzi in areas with and without domestic vectorial transmission in Minas Gerais, Brazil. Mem. Inst. Oswaldo Cruz 90: 443-448.

ENGEL, L.A. \& D.A. MELLo. 1993. Rodents in agroecosystems in the Cerrado Province of the Federal District (Brasilia/DF, Brazil). Cienc. Cult. 45 (2): 128-133.

ERNEST, K.A. \& M.A. MARES. 1986. Ecology of Nectomys squamipes, the neotropical water-rat in Central Brazil: Home range, habitat selection, reproduction and behaviour. Jour. Zoology 210: 599-612

FONSECA. G.A.B. \& J.G. ROBINSON. 1990. Forest size and structure: competitive and predatory effects on small mammals communities. Biological conservation. 53: 265-294.

GENTILE, R.; P.S. D'ANDREA \& R. CERQueIRA. (In press). Home ranges of Philander frenata and Akodon cursor in a Brazilian Restinga (Coasta shrub land). Mastozoologia Neotropical.

GALLANTE, M.L. \& M.H. CASSINI. 1994. Seasonal variation of a Cavy population in the Pampa region, east-central Argentina. Mammalia 58: 549-546.

Hingst, E.D.; P.S. D’ANDREA \& R. CERQueira. 1998. Breding of Philander opossum (Didelphimorphia, Didelphidae) in captivity. Lab. Animals 32: 434438.

MagurRam, A.E. 1988. Ecological diversity and its measurements. Croom Helm, Australia, 178p.

MELlo, D.A. 1991. Parasitic diseases in Brazil and the role of wild mammals: an analysis based on leishmaniasis, Chagas' disease and schistosomiasis mansoni. Cienc. Cult. 43 (4): 274-278.

Mills, J.N.; B.A. Ellis; K.T. McKeE; J.I. MaizTegui \& J.E. Childs. 1992. Reproductive characteristics of rodent assemblages in cultivated regions of central Argentina. Jour. Mamm. 73 (3): 515-526.

MutZE, G.J. 1990. Mouse plagues in South Australian cereal-growing areas. I. Occurrence and distribution of plagues. Aust. Wild. Res. 16: 677-683

NiMER, E. 1989. Climatologia do Brasil. Rio de Janeiro, IBGE, 422p.

Paglia, A.P.; P. DE Marco; F.M. Costa; R.F. Pereira \& G. Lessa. 1995.

Heterogeneidade estrutural e diversidade de pequenos mamíferos em um fragmento de mata secundária de Minas Gerais, Brasil. Rev. Brasil. Biol. 12: 69-79. PASSAMANI, M. 1995. Vertical stratification of small mammals in south-eastern 
Brazil's Atlantic Hill Forest. Mammalia 65: 505-508.

REY, L. 1993. Non-human vertebrate hosts of Schistosoma mansoni and schistosomiasis transmission in Brazil. Res. Rev. Parasitol. 53 (1-2): 13-25.

SOULÉ, M.E. \& B.A. WILCOX. 1980. Conservation Biology: an evolutionary-ecological perspective. Massachusetts, Sinauer Associates Inc. Publ., 395p.

StallingS, J.R.; G.A.B. FonseCA; L.P.S. Pinto; L.M.S. Aguiar; E.L. SÁbato. 1991. Mamíferos do Parque Florestal Estadual do Rio Doce, Minas Gerais, Brasil. Revta bras. Zool. 7 (4): 663-677.

ZAR, J.H. 1996. Biostatistical Analysis. New Jersey, Prentice Hall, Englewood Cliffs, 662p.

Recebido em 19.XII.1997; aceito em 12.V.1999. 